\title{
ANALISIS NILAI CLOTHING TIME, PROTHROMBINE TIME DAN ACTIVATED PARTIAL THROMBOPLASTINE TIME PADA REMAJA OBES
}

\section{ANALYSIS CLOTHING TIME, PROTHROMBINE TIME AND ACTIVATED PARTIAL THROMBOPLASTINE TIME VALUE IN OBESE ADOLESCENT}

\author{
Nelly ${ }^{1}$, Mansyur Arief ${ }^{2}$, Ilham Jaya Patellongi ${ }^{3}$ \\ 1 Bagian Biomedik Fisiologi Fakultas Kedokteran Universitas Muhammadiyah \\ 2 Bagian Patologi Klinik FK. Universitas Hasanuddin-RSUP.dr.Wahidin Sudirohusodo Makassar \\ 3 Bagian Fisiologi FK Universitas Hasanuddin Makassar
}

\begin{abstract}
ABSTRAK
Berdasarkan estimasi WHO, obesitas menjadi masalah kesehatan di dunia. Selain karena insidennya meningkat,juga karena obesitas menimbulkan berbagai komplikasi penyakit metabolik dan vaskuler seperti sindrom metabolik, penyakit jantung, stroke dan gangguan pembekuan darah. Mengingat insiden obesitas pada saat ini telah mengalami pergeseran dari dewasa ke usia anak dan remaja serta berbagai komplikasi yang ditimbulkan oleh obesitas itu sendiri maka dianggap perlu dilakukan deteksi dini adanya gangguan hemostasis pada obesitas usia anak dan remaja untuk mencegah komorbiditas obesitas dikemudian hari. Desain penelitian ini adalah cross sectional study yang dilakukan di SMA Katolik Rajawali Makassar dengan menggunakan sampel siswa yang berumur sekitar 10-18 tahun. Dilakukan pemeriksaan antropometrik dan pemeriksaan nilai Clothing Time (TT), Prothrombine Time (PT) dan Activated Partial Thromboplastine Time(aPTT). Obesitas dinyatakan berdasarkan Kategori IMT yang ditentukan berdasarkan ambang batas Z-Score sedangkan kategori lingkar pinggang ditentukan berdasarkan W aist Circumfrence for Hong Kong Chinese Children (2008). Data dianalisis dengan independent t-test untuk menilai perbedaan nilai CT, PT dan aPTT pada remaja obes dan berat badan normal sedangkan uji korelasi pearson digunakan untuk melihat adanya hubungan antara IMT dan LP dengan nilai CT, PT dan aPTT pada remaja obes. Subyek adalah siswa siswi SMA Katolik Rajawali Makassar dengan rerata umur 15 tahun terdiri dari 33 orang laki-laki (22 obesitas, 11 normal) dan 16 perempuan (5 obesitas,11 normal). Didapatkan perbedaan bermakna antara nilai CT, PT dan aPTT pada remaja obes dan berat badan normal. Nilai rata-rata CT, PT dan pada kelompok normal adalah masing-masing aPTT 11 $\pm 1,23$ ; 13,86 \pm 0,63 detik ; 32,90 \pm 1,77 detik dan pada kelompok obes adalah nilai CT,PT dan aPTT adalah $9 \pm 1,7$; 13,11 \pm 0,59 detik dan 31,92 $\pm 3,82$ detik. Selain itu, terdapat korelasi negatif antara nilai CT,PT dan LP pada remaja obes namun tidak ditemukan adanya korelasi antara IMT dan LP dengan nilai aPTT pada remaja obes. Nilai CT, P'T dan aPT'T pada remaja obes cenderung memendek dibandingkan dengan berat badan normal. Semakin tinggi nilai IMT dan LP, maka nilai CT, PT dan aPTT semakin memendek.
\end{abstract}

Keywords : obesitas, remaja CT,PT,aPTT

\begin{abstract}
Based on World Health Organization estimation, obesity has been a world health problem. Aside from the increased incident, also because obesity causes various vascular and metabolic disease complications such as metabolic syndrome, heart disease, stroke and blood coagulation disorder. Considering that the obesity syndrome now has shifted from adults to kids and adolescent along with the complications of obesity, it is necessary to get an early detection in haemostatic disorder in kids and adolescent obesity to prevent obesity co morbidity in the future. The design of the research is cross sectional study which was carried out the population of Katolik Rajawali High School student in Makassar, ranging in age from ten to eighteen years old. An anthropometric examination was done, as well as examination of Clothing Time (TT), Prothrombine Time (PT) and Activated Partial Thromboplastine Time (PTT) value. Obesity is declare based on Body Mass Index (BMI) Category which was determined based on Z-Score threshold whereas waist line category was determined based on Waist Circumference (WC) for Hong Kong Chinese Children (2008). Data was analyzed
\end{abstract}


using an independent t-test to assess the difference in CT, PT and aPTT value in obese adolescent and normal weight whereas the Pearson correlation test was used to see the relation between BMI and WC with CT, PT and aPTT in obese adolescent. Subjects were the high school students with the average age of 15 years old, consisting of 33 boys ( 22 obese, 11 normal) and 16 girls (5 obese, 11 normal). The results showed significance different between CT, PT and aPTT value in obese adolescent and normal weight. The mean CT, PT and aPTT in the normal group were each $11 \pm 1.23 ; 13.86 \pm 0.63$ seconds; $32.90+1.77$ seconds and in the obese group the CT value, PT and aPTT were $9 \pm 1.7 ; 13.11+0.59$ seconds and $31.92+3.82$ seconds. Besides that, there was a negative correlation between CT, PT and WC value in obese adolescent but there was no correlation between BMI and WC with aPTT value in obese adolescent. Clothing Time, PT and aPTT value in obese adolescent tends to shorten compared to normal weight. The higher BMI and WC values, the shorter CT, PT and aPTT values.

Keywords : Obesity, adolescent,CT, PT,aPTT

\section{PENDAHULUAN}

Obesitas merupakan masalah di seluruh dunia baik di negara maju maupun negara berkembang baik karena prevalensinya yang meningkat dari tahun ke tahun,juga karena obesitas dianggap sebagai faktor resiko penyebab penyakit metabolik dan vaskuler, yang diawali oleh hipertensi, dyslipidemia, inflamasi kronik, pembekuan darah dan hiperinsulinemia. ${ }^{1,2}$ Penyakit ini dilaporkan meningkat seiring dengan meningkatnya kejadian obesitas. Berdasarkan hasil survey kesehatan nasional dan rumah tangga di Indonesia Pada tahun 2001 penyakit jantung iskemik meningkat dari $2,5 \%$ menjadi $14,9 \%$, kejadian stroke meningkat dari 5,5\% menjadi $11,5 \%$ dan kanker meningkat dari 3,4\% menjadi $7 \% .^{3}$

Berkurangnya aktivitas fisik dan berkembangnya makanan cepat saji menyebabkan perubahan gaya hidup menjadi obesogenik yang tidak hanya terjadi pada orang dewasa tetapi juga pada remaja dan anak-anak Sehingga hal ini menyebabkan pergeseran kejadian obesitas pada usia yang lebih muda. Insiden obesitas pada periode transisi antara remaja dan dewasa muda dalam kurun waktu lima tahun meningkat dari $10,9 \%$ menjadi $22,1 \% .{ }^{4}$

Obesitas dengan berat badan berlebihan ditandai dengan hipertofi jaringan adiposa. Jika sel-sel adiposit dan jaringan adiposa tetap sehat selama berat badan bertambah, pasien dapat terhindar dari penyakit metabolik. Namun, jika hipertofi sel-sel adiposit dan jaringan adiposa menyebabkan sel-sel menjadi "sakit" (Sick fat cell),maka fungsi jaringan adiposa akan terganggu. ${ }^{5}$ Sel-sel adiposit dan jaringan adiposa yang sakit akan melepaskan Free Fatty Acid (FFA) dan mediator inflamasi yang memicu terjadinya stress oxidative dan menimbulkan kerusakan endotel vaskuler yang merupakan awal dimulainya cascade koagulasi sehingga terjadi gangguan hemostasis., ${ }^{6,7}$ Selain itu, peningkatan asam lemak bebas menyebabkan peningkatan produksi glukosa di hepar dan penurunan uptake glukosa di otot yang keduanya menyebabkan resistensi insulin. Peningkatan FFA juga menyebabkan peningkatan ekspresi Uncoupling Protein (UCP) yang dapat menurunkan produksi ATP yang dibutuhkan dalam sintesis insulin. Selain itu, keadaan obesitas diyakini mengganggu hemostasis baik primer Vol. 1 No.5 Agustus 2018 
(Clothing Time) maupun sekunder (PT dan aPTT) $)^{7}$

Deteksi dini adanya gangguan hemostasis terutama pada anak atau remaja yang obes sangatlah penting untuk mencegah komorbiditas obesitas dikemudian hari. Penelitian ini bertujuan untuk menganalisa adanya perubahan nilai CT, PT dan aPTT pada remaja yang mengalami obesitas.

\section{METODE}

Penelitian dilakukan di SMA Katolik Rajawali Makassar pada kelompok remaja yang berumur sekitar 10-18 tahun. Dari 49 sampel diperoleh 27 remaja yang tergolong obes dan 22 orang dengan berat badan normal dengan perbandingan laki-laki 2 kali lebih banyak dibandingkan perempuan. Kriteria inklusi adalah siswa yang IMTnya memenuhi kriteria obesitas berdasarkan Z Score dan kategori lingkar pinggang ditentukan berdasarkan Waist Circumfrence for Hong Kong Chinese Children (2008). Kriteria eksklusi adalah siswa yang saat ini sedang mengkonsumsi obat-obatan, seperti antibiotik, antikoagulan, anti inflamasi dan obat-obat diet yang dapat mempengaruhi hasil pemeriksaan serta memiliki riwayat penyakit perdarahan. Setiap subyek terpilih diberikan informed concent dan ijin penelitian diperoleh dari orang tua. Ethnical clearance diperoleh dari Komite Etik Penelitian Fakultas Kedokteran Universitas Hasanuddin Makassar.

Analisis data menggunakan SPSS for Windows dengan menggunakan uji independent $t$-test untuk mengetahui perbedaan nilai CT, PT dan
aPTT dan uji korelasi Pearson untuk menentukan hubungan antara IMT dan LP dengan nilai CT, PT dan aPTT.

\section{HASIL DAN PEMBAHASAN}

Dari 49 sampel diperoleh 33 orang $(67.3 \%)$ laki-laki dan 16 orang (32.6\%) perempuan. Adapun jumlah sampel yang memenuhi kriteria obesitas sebanyak 27 orang (57.1\%) dan yang tidak memenuhi kriteria obesitas sebanyak 22 orang (42.9\%).

Tabel 1. Perbedaan Nilai PT dan aPTT Antara Obes dan BB Normal pada Remaja Kategori Obes BB Normal

Mean $P \quad$ Mean $\pm \quad P$
$\pm \mathrm{SD} \quad \mathrm{SD}(\mathrm{dtk})$ (dtk)

$\begin{array}{ccccc}\text { CT } & 11 \pm & & 9 \pm 1,7 & \\ \text { PT } & 1,23 & 0,024 * & 13,11 \pm & 0,000^{*} \\ \text { aPTT } & 13,86 & & 0,59 & \\ & \pm 0,63 & & 31,92 \pm 3 & \\ & 32,90 & & & \\ 10 & \pm 1,77 & & & \end{array}$

* independent sample $\mathrm{T}$ test, signifikan jika $\mathrm{P} \leq$ 0,05

Berdasarkan Tabel 1, terlihat ada perbedaan bermakna $(\mathrm{p}<0,001)$ antara nilai $\mathrm{CT}$, PT dan aPTT antara remaja obes dengan berat badan normal. Dimana Nilai CT, PT dan aPTT lebih rendah (memendek) pada kelompok remaja obes dibandingkan berat badan normal. Meskipun baik nilai CT, PT maupun nilai aPT'T pada kedua kelompok masih berada dalam batas normal.

Dari Tabel 2 terlihat bahwa terdapat hubungan linier antara lingkar pinggang dan IMT 
dengan Nilai CT dan PT. Arah korelasi negatif berarti semakin tinggi lingkar pinggang dan IMT maka nilai CT dan PT semakin memendek. Dari tabel di atas juga terlihat bahwa tidak terdapat hubungan linier antara LP dan IMT dengan nilai aPTT.

\begin{tabular}{cccccc}
\hline & $\mathrm{r}$ & $\mathrm{P}$ & $\mathrm{R}$ & $\mathrm{p}$ & \\
\hline LP & - & 0,000 & - & 0,004 & $\mathrm{~S}$ \\
IMT & 0,697 & 0,000 & 0,423 & 0,127 & $\mathrm{NS}$ \\
& - & & - \\
& 0,570 & & 0,120 & & \\
\multicolumn{2}{c}{ *Signifikan jika $\mathrm{p}<0,05$}
\end{tabular}

Tabel 4. Korelasi Bivariat dan Partial Lingkar Pinggang dengan nilai PT

\begin{tabular}{|c|c|c|c|c|c|}
\hline \multirow{3}{*}{ Variabel } & \multicolumn{4}{|c|}{ Prothombine Time } & \multirow{3}{*}{$\mathrm{NS} / \mathrm{S}$} \\
\hline & \multicolumn{2}{|c|}{ Bivariate } & \multicolumn{2}{|c|}{ Partial } & \\
\hline & $\mathrm{r}$ & $\mathrm{P}$ & $\mathrm{R}$ & p & \\
\hline LP & - & 0,000 & - & 0,008 & $\mathrm{~S}$ \\
\hline IMT & 0,607 & 0,000 & 0,348 & 0,266 & NS \\
\hline
\end{tabular}

Tabel 3. Korelasi Bivariat dan Partial Lingkar Pinggang dengan nilai CT

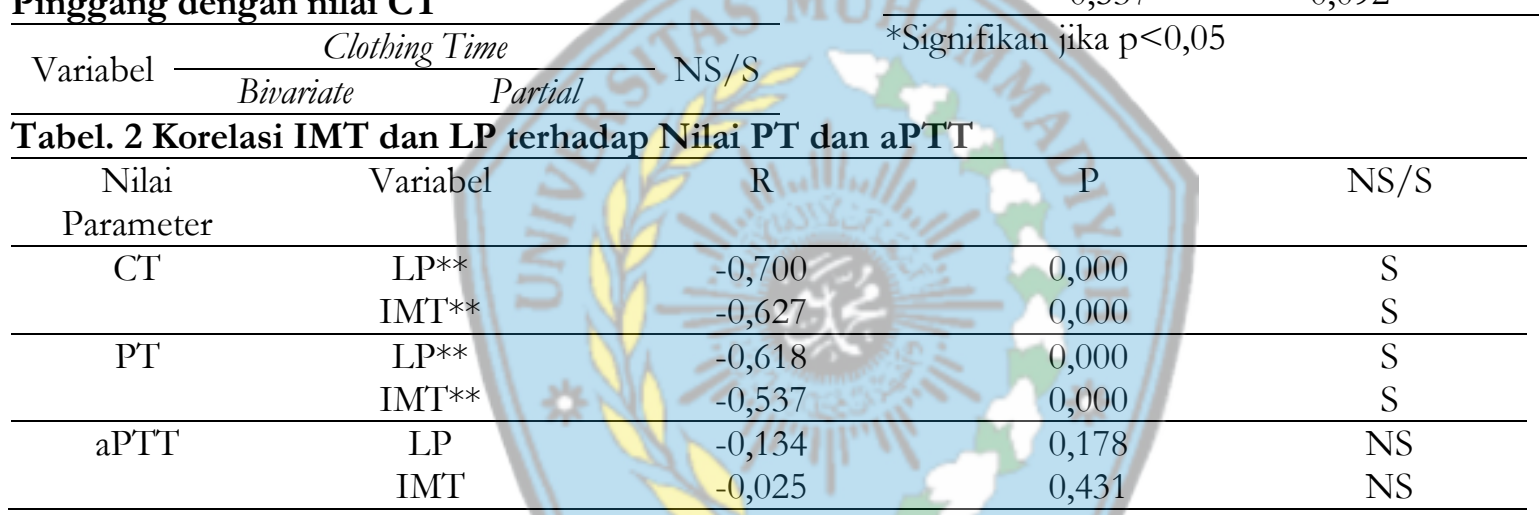

** Pearson Correlation test (1-tailed); $\mathrm{p}$ signifikan bila $\leq 0,05$

Pada Tabel 3 dan 4 terlihat bahwa Setelah variabel IMT dikendalikan, kekuatan korelasinya tetap lemah. Berdasarkan nilai $\mathrm{p}$ yang diperoleh menunjukkan bahwa lingkar pinggang memiliki korelasi yang signifikan dengan Nilai CT dan PT dibandingkan dengan IMT.

\section{PEMBAHASAN}

Pada penelitian ini ditemukan adanya perbedaan bermakna antara nilai CT, PT dan aPT'T pada remaja obes dengan normal. Nilai CT, PT dan aPTT lebih rendah (memendek) dibandingkan pada orang normal. Obesitas terutama obesitas viseral merupakan keadaan inflamasi kronik derajat rendah baik akibat pelepasan mediator inflamasi,peningkatan asam lemak dalam sirkulasi maupun resistensi insulin. ${ }^{8}$ Pelepesan mediator inflamasi seperti interleukin 6 (IL-6), tumor necorsis factor- $\alpha(\mathrm{TNF}-\alpha)$ dan monocyte chemotatic protein-1 (MCP-1) yang menandai awal terjadinya inflamasi. Interleukin 6 dan TNF- $\alpha$ dapat memicu pembentukan Creactive protein (CRP) di hati. Protein ini jika diproduksi terus menerus dapat memperburuk kondisi inflamasi melalui aktivasi kronik terhadap sel endotel, akibatnya terjadi disfungsi endotel.9,10 
Disfungsi endotel didefinisikan sebagai penurunan sintesis dan sekresi NO meskipun pada angiografi belum ditemukan penyakit. ${ }^{11}$ Selain itu, disfungsi endotel dapat disebabkan oleh resistensi insulin. ${ }^{12}$ Namun saat ini masih menjadi perdebatan apakah inflamasi merupakan penghubung obesitas dengan resistensi insulin atau respon inflamasi terjadi setelah terjadi resistensi insulin. ${ }^{8}$

Hubungan antara resistensi insulin dan inflamasi kronik bersifat timbal balik. Adanya inflamasi kronik akan menurunkan kerja insulin dan adanya resistensi insulin akan memperburuk keadaan inflamasi. ${ }^{13}$ Insulin melalui mekanisme phosphatidylinositol 3-kinase (PI3-K) pathway akan merangsang produksi NO oleh endotel sedangkan pada keadaan resistensi insulin terjadi insulin-mediated glucose transport yang tidak efektif dan gangguan produksi $\mathrm{NO}$ akibat defek PI3-K signaling namun jalur mitogenactivated protein kinase (MAPK) masih berfungsi normal. Insulin melalui jalur MAPK bersifat proaterogenik karena meningkatkan potensi platelet- derived growth factor (PDGF) sehingga terjadi proliferasi sel otot polos vaskular. ${ }^{14}$ Manifestasi awal terjadinya peningkatan stress oksidatif vaskular ditandai dengan penurunan ketersediaan NO akibat penghambatan terhadap eNOS dan katabolisme cepat NO oleh reactive oxygen species (ROS) menjadi peroksinitrit dan hidrogen peroksida yang dapat meningkatkan stress oksidatif vaskular. Akibatnya terjadi kelainan aktifitas vasomotor, pembentukan prokoagulan pada permukaan endotel, inflamasi dan pembentukan plak. ${ }^{15}$

Kerusakan endotel vaskuler akan menyebabkan terpaparnya faktor jaringan (TF) yang diproduksi oleh endotel vaskuler dan trombosit yang merupakan mekanisme awal dimulainya gangguan hemostasis dan jika keadaan ini berlanjut dimana plug yang terbentuk tidak stabil atau jejas yang lebih bedar akan mengganggu hemostasis sekunder baik pada jalur ekstrinsik maupun intrinsic. untuk membentuk thrombin. begitu terbentuk sedikit thrombin, maka thrombin akan mengaktifkan faktor IX menjadi FIXa lebih lanjut, sehingga proses koagulasi dilanjutkan oleh jalur intrinsik. ${ }^{16,17}$

Pada remaja obes, baik nilai CT, PT dan aP'TT masih berada dalam batas normal mengingat remaja masih mengalami tahap pertumbuhan sehingga hipertropi jaringan adipose belum mengalami adiposopathy. Selain itu, metabolisme masih berlangsung optimal sehingga pembentukan ATP dapat mencegah terjadinya resistensi insulin. Selain itu, pelepasan mediator proinflamasi dan antiinflamasi masih dalam homeostasis sehingga kerusakan endotel vaskuler tidak berlangsung secara terus menerus. Memendeknya nilai CT, PT dan aPTT dapat disebabkan oleh diet tinggi lemak. ${ }^{18}$ Penelitian yang dilakukan oleh Kaji et al menunjukkan nilai PT dan aPTT pada tikus obes lebih rendah secara signifikan dibandingkan dengan tikus yang diberi diet standar.

Diet tinggi lemak merupakan salah satu faktor yang dapat menyebabkan memendeknya nilai CT, PT dan aPTT. ${ }^{18}$ Hiperglikemia yang 
terjadi setelah rnakan akan meningkatkan konsentrasi malonil koA di dalam sel B. Malonil koA menghambat karnitin palmitoil transferase-1, dan mengganggu transport asil koA lemak ke dalam mitokondria di mana ia akan dioksidasi melalui siklus Krebs. Peningkatan asil ko $\mathrm{A}$ lemak di sitosol bekerja sejalan dengan keadaan hiperglikemia untuk memperkuat sekresi insulin. Konsisten dengan observasi in vitro ini, peningkatan konsentrasi asam lemak plasma jangka pendek (2 sampai 6 jam) diketahui meningkatkan sekresi insulin pada rodensia dan manusia, dan sebaliknya, penurunan akutnya akan menghambat sekresi insulin yang distimulasi oleh glukosa. ${ }^{19}$ Selain itu, proses lipolisis yang tinggi menyebabkan jumlah stress oksidatif yang dihasilkan juga sangat tinggi. Terjadi peningkatan jumlah reactive oxygen species (ROS) akibat peningkatan aktivitas enzim oksidase dan disregulasi hormon adipositas. Peningkatan stress oksidatif menyebabkan gangguan metabolisme, baik asupan glukosa pada otot maupun pada jaringan adipose, penurunan sekresi insulin dan kerusakan sel sehingga terjadi disfungsi endotel, aterosklerosis sampai akhirnya terjadi penyakit vaskuler. Tubuh kita memiliki mekanisme defensive terhadap stress oksidatif. Superoksida dismutase (SOD), glutathione peroxidase (GPX) dan katalase merupakan enzim yang dapat mendegradasi ROS. Superoksida dismutase mengubah superoksida menjadi hydrogen peroksida (H2O2) dan molekul oksigen (O2). Penurunan aktivitas SOD merupakan penanda penting stress oksidatif dan meningkatkan resiko disfungsi endotel dan gangguan hemostasis..$^{20,21}$

Gangguan hemostasis terutama pada obesitas viseral ditandai oleh hiperagregasi platelet,hiperkoagulasi, hipofibrinolisis akibat peningkatan PAI-1 dan disfungsi endotel. ${ }^{21}$ Disfungsi endotel vaskuler dan peranan trombosit merupakan awal dimulainya proses koagulasi dan proses ini akan berlanjut melalui jalur ekstrinsik yang diwakili oleh Prothrombine Time (PT) dan melibatkan F.VII dan berlangsung singkat akibat dihambat oleh Tissue Factor Pathway Inhibitor (TFPI). Setelah terbentuk thrombin, proses koagulasi dilanjutkan oleh jalur ekstrinsik yang diwakili oleh Activated Partial Thromboplastin Time (aPTT) dan melibatkan banyak faktor seperti FXII,FIX,FVIII,HMWK dan PK.22,23 Hal ini dianggap sebagai salah satu faktor penyebab tidak adanya korelasi antara obesitas dan nilai aPTT.

Lingkar pinggang terutama menunjukkan besar lemak tubuh viseral dan sedikit sekali pengaruh massa tulang dan otot. Jaringan adipose viseral lebih aktif melepaskan mediator proinflamasi dibandingkan dengan jaringan adipose perifer. ${ }^{24}$

Penelitian ini masih membutuhkan penelitian lebih lanjut mengenai gangguan pembekuan darah pada remaja obes terutama dengan sampel yang lebih besar dan menggunakan kriteria seperti adanya sindrom metabolik dan parameter lain untuk melihat adanya gangguan hemostasis pada remaja obes seperti protein $\mathrm{C}$ dan Protein S. 


\section{KESIMPULAN}

Nilai CT, PT dan aPTT pada remaja obesitas masih dalam batas normal meskipun nilainya lebih rendah dibandingkan dengan remaja normal. Selain itu, ditemukan adanya korelasi bermakna antara nilai CT dan PT dengan lingkar pinggang dengan korelasi yang lemah.

\section{DAFTAR PUSTAKA}

1. Mexitalia,M., Agustini Utari, Sakundarno M, Taro Yamauchi, Hertanto Wahyu Subagio, Agustinus Soemantri. Sindrom Metabolik pada Remaja Obesitas, Dalam : Media Medika Indonesiana, Jawa Tengah, Fakultas Kedokteran Universitas Diponegoro dan Ikatan Dokter Indonesia Wilayah Jawa Tengah. 2011.

2. Ferguson MA, Gutin B, Owens S, Litaker M, Tracy RP, Allison J. Fat Distribution and Hemostatic Measures in Obese Children. Am J Clin Nutr 1998; 67: 1136 40

3. Dietz WH, Suskind,RM, Suskind L(Eds). Childhood Obesity. In : Textbook of Pediatric Nutrition. 2nd ed., New York, Raven Press,1993;279-84.

4. Cole TJ, Bellizi MC, Flegal KM, Dietz WH., 2000 : Establishing a Standard Definition for Child Overweight and Obesity Worldwide: International Survey. BMJ ;320:1240-1243

5. Lawrence GS. Implikasi Klinis Disfungsi Endotel dan Radikal Bebas. Unit Riset Vaskuler, Bagian patologi, Makassar, FKUH RSUP dr.Wahidin Sudirohusodo, 2006.

6. Verma S, Buchanan MR, Anderson TJ.Endothelial Function Testing as a Biomarker of Vascular Disease. Circulation 2003;108:2054-9.
7. Hajer GR, Timo W.Van Haeften and Frank LJ Visseren. Adipose Tissue Dysfunction in Obesity, Diabetes and Vascular Disease. Departement of Vascular Medicine, The Netherlands University Medical Center Urecht, European Heart Journal (2008) 29, 29597

8. Heru Cahjono, Anak Agung Gde Budhiarta. Hubungan Resistensi Insulin dengan Kadar Nitric Oxide pada Obesitas Abdominal. Bagian / SMF Ilmu Penyakit Dalam FK Unud / RS UP Sanglah, Denpasar Bali. Hal:23-6

9. Steven E. Shoelson, Laura Herrero, And Afia Naaz. Obesity, Inflammation, and Insulin Resistance. Joslin Diabetes Center and Department of Medicine, Harvard Medical School, Boston, Massachusetts.Journal of Gastroenterology. 2007;132:2169-21

10. Ruhbeck G, Ambrosi JG, Muruzabal FJ, Burrell MA. The Adipocyte: a Model for Intergration of Endocrine and Metabolic Signaling in Energy Metabolism Regulation. Am J Physiol Endocrinol Metab 2001; 280: 827-47.

11. Iiao JK. Endothelium and Acute Coronary Syndrome. Clin Chem 1998;44(8):1799-808.

12. Hu SK, Wang ZM, Shen W, Heymsfield SB, Heshka S. Percentage Body Fat Ranges Associated with Metabolic Syndrome Risk : Results Based on The Third National Health and Nutrition Examination Survey. Am J Clin Nutr 2003; 78: 228-35.

13. Fernandez-Real JM, Ricart W. Insulin Resistance and Chronic Cardiovascular Inflammatory Syndrome. Endocrine Reviews 2003;24(3):278-301.

14. Hsueh WA, Jackson S, Law RE. Control of Vascular Cell Proliferation and Migration by Ppar-X-A New 
Approach to The Macrovascular Complication of Diabetes. Diabetes Care 2001;24;392-7.

15. Cohn JN, Quyyumi AA, Hollenberg NK, Jamerson KA. Surrogate Markers for Cardiovascular Disease - Functional Markers. Circulation 2004;109(suppl IV):IV31-46.

16. Sfinger Link. Metabolic, Inflamatory, Endhothelial and Haemostatic Markers in a Group of Italian Obese Children an Adolescent. European Journal of Pediatric. 2011; 170 (7) :845-50

17. I Made Bakta, Thrombosis pada Usia Lanjut. Denpasar,Bali,Universitas Udayana RS.Sanglah, 2007; 8 (2) : 147-58

18. Mira Dewi. Resistensi Insulin Terkait Obesitas. Dalam : Mekanisme Endokrin dan Intrinsik Sel. Jurnal Gizi dan Pangan Pergizi Pangan Indonesia. Bogor Indonesia. Juli 2007;1978(2) :49-54

19. Grey A. The Reductive Hotspot Hypothesis: An Update. Arch Biochem Biophys 2000; 373: 295-301.
20. Irène Juhan-Vague MD, Marie-Christine Alessi MD. Abdominal Obesity,Insulin Resistance, and Alterations in Hemostasis. Laboratoire d'Hématologie, Faculté de Médecine, Université de la Méditer- ranée, Inserm UMR 626, Marseille,France. ijuhan@ap-hm.fr. 2008:11-16

21. Koletzko B, Girardet JP, Klish W, Tabacco O. Obesity in Children and Adolescents Worldwide : Current Views and Future Directions, Working Group Report of the First World Congress of Pediatric Gastroenterology, Hepatology, and Nutrition. J Pediatr Gastroenterol Nutr.2002 ; 35:S205-12.

22. Darvall KAL, Silveman SH,et al. Obesity and Thrombosis. Department of Vascular Surgery. City Hospital, Birmingham UK and University Department of Vascular Surgery, Birmingham Heartlands Hospital, UK. 2007 ; 223-233

23. Eckel R, Grundy S. Insensitivity to Insulin and Obesity: The Underlying Cause. Diabetes Voice 2006;51:28-30. 